\title{
Field Studies on the Relationship between Fusarium verticillioides and Maize (Zea mays L.): Effect of Biocontrol Agents on Fungal Infection and Toxin Content of Grains at Harvest
}

\author{
Paola Pereira, ${ }^{1}$ Andrea Nesci, ${ }^{1}$ Carlos Castillo, ${ }^{2}$ and Miriam Etcheverry ${ }^{1}$ \\ ${ }^{1}$ Laboratorio de Ecología Microbiana, Departamento de Microbiología e Inmunología, Facultad de Ciencias Exactas, Físico-Químicas \\ y Naturales, Universidad Nacional de Río Cuarto, Ruta Nacional 36 Km 601, Río Cuarto, 5800 Córdoba, Argentina \\ ${ }^{2}$ Departamento de Producción Vegetal, Facultad de Agronomía y Veterinaria, Universidad Nacional de Río Cuarto, \\ Ruta Nacional 36 Km 601, Río Cuarto, 5800 Córdoba, Argentina
}

Correspondence should be addressed to Miriam Etcheverry, metcheverry@exa.unrc.edu.ar

Received 29 March 2011; Accepted 17 May 2011

Academic Editor: Robert J. Kremer

Copyright () 2011 Paola Pereira et al. This is an open access article distributed under the Creative Commons Attribution License, which permits unrestricted use, distribution, and reproduction in any medium, provided the original work is properly cited.

\begin{abstract}
Maize (Zea mays L.) is a staple food for the majority of the world's population. Fusarium verticillioides (Sacc.) Nirenberg (Teleomorph: Gibberella moniliformis Wineland; synonym: F. moniliformis) is both a saprophyte and a parasite of maize and can also be found as an endophyte. The presence of this fungus in maize constitutes an imminent risk due to its ability to produce fumonisins, mycotoxins with proven carcinogenic effects. The present work investigated biocontrol activity of Bacillus amyloliquefaciens and Microbacterium oleovorans against F. verticillioides infection and fumonisin $\mathrm{B}_{1}$ production in field-grown maize during four consecutive growing seasons. Treatment with B. amyloliquefaciens consistently reduced F. verticillioides inoculum and fumonisin content of harvested grains. F. verticillioides count and fumonisin levels correlated negatively with rainfall regimes; however, none of these parameters showed significant correlation with yields. Treatment with these biocontrol agents may improve phytosanitary quality of the grains and reduce toxicological risk in the maize agroecosystem.
\end{abstract}

\section{Introduction}

Maize (Zea mays L.) is a staple food for the majority of the world's population together with wheat and rice [1]. The maize crop is currently the third most traded cereal with a total production of 817 million tones in over 159 million hectares by 2009 [2]. About 35 to $40 \%$ of maize annual production of Argentina is obtained in Córdoba province [3]. Maize is mainly used as a food source but it has become the most important raw material for animal feed and for several industrial processes $[4,5]$. An increasing area is now being used to cultivate this crop, not only in temperate agroecological zones but also in all sorts of edaphic, altitudinal, and fertility conditions; which explains its global adaptability and its many types of varieties [6].

In spite of this versatility, maize, as well as the rest of the agronomic crops, is not exempt of suffering from different diseases affecting its emergence, growth, development, and yield. Plant diseases cause global losses ranging between 9 and $22 \%$ of annual production, depending mainly on the crop and technological development of the country where the crop is [7].

Fusarium verticillioides (Sacc.) Nirenberg (Teleomorph: Gibberella moniliformis Wineland; synonym: F. moniliformis) is both a saprophyte and a parasite of maize; it can be found as a systemic endophyte in a symptomless biotrophic state or as a hemibiotrophic pathogen depending on environmental conditions $[8,9]$. Regardless the occurrence of symptoms, the presence of this fungus in maize constitutes an imminent risk due to its ability to produce fumonisins, mycotoxins with proven carcinogenic effect on rats, swine, and equines and already classified by the International Agency for Research on Cancer as possible carcinogens to humans [10].

Different strategies such as good agricultural practices, for example, intercropping and rotation; the judicious use of pesticides; exploiting the gene pool of the plant in 
breeding programs and understanding and combating virulence mechanisms of the pathogens [11], arise as prevailing mechanisms to alleviate the problem of plant diseases. However, the minority of cited strategies are available or effective in F. verticillioides-maize interactions, mainly due to the endophytic asymptomatic state that the fungus can attain when infecting the crop. In addition, traditionally applied synthetic chemical pesticides, with demonstrated harmful effects on the environment $[12,13]$, lose effectiveness against microorganisms occupying the endophytic niche.

The aim of the present work was to evaluate if biological control may represent a consistent alternative for reducing $F$. verticillioides infection of field-grown maize and fumonisin content of grains at harvest. Assays were performed during four consecutive maize growing seasons in Río Cuarto, Córdoba province, central area of Argentina.

\section{Materials and Methods}

2.1. Biocontrol Agents. Bacillus amyloliquefaciens isolate 1 (Genbank accession number EU164542) and Microbacterium oleovorans isolate 2 (Genbank accession number EU164543) were used in the different field assays. Strains were originally isolated from a commercial maize field and identified on the basis of $16 \mathrm{~S}$ rDNA gene sequence similarity and additionally identified from axenic cultures based on morphophysiological characteristics following criteria described by Slepecky and Hemphill [14] and Holt et al. [15]. Biocontrol activity of these bacterial agents against $F$. verticillioides was already proved under greenhouse conditions [16]. Both isolates were deposited in the Banco Nacional de Microorganismos-Instituto de Investigaciones en Biociencias Agrícolas y Ambientales (INBA) and Consejo Nacional de Investigaciones Científicas y Técnicas (CONICET) accession numbers BNM0531 and BNM0532. Strains were stored at $-20^{\circ} \mathrm{C}$ in glycerol and, when required for experimental use, they were transferred to nutrient agar (meat extract $3 \mathrm{~g}$, soy peptone $5 \mathrm{~g}, \mathrm{NaCl} 8 \mathrm{~g}$, agar $15 \mathrm{~g}$, distilled water $1000 \mathrm{ml}$ ). Nutrient broths were also prepared and sterilized, inoculated with either B. amyloliquefaciens or M. oleovorans and incubated at $28^{\circ} \mathrm{C}$ with shaking (100 rpm) until late log phase to obtain inoculums of biocontrol agents (BCAs). Total numbers of viable cells were determined by standard plate count methods, and suspensions of $10^{9} \mathrm{CFUs} \mathrm{mL}^{-1}$ were used to introduce bacteria as maize seed coatings.

2.2. Plant Material. The experiments were carried out with maize seeds of DK684RR2 cultivar (Monsanto). Characteristics of this material are presented in Table 1.

2.3. Field Assays. Treatments and Experimental Area. Three treatments were performed at the University of Río Cuarto Experimental Field Station in Río Cuarto, Córdoba, Argentina $\left(30^{\circ} 57^{\prime} \mathrm{S}\right.$ latitude, $64^{\circ} 50^{\prime} \mathrm{W}$ longitude, $562 \mathrm{~m}$ altitude) during four consecutive maize growing seasons (20042005, 2005-2006, 2006-2007, and 2007-2008). For treatment 1 (T1: control), 300 maize seeds were submerged in $300 \mathrm{ml}$ of sterile saline solution ( $\mathrm{NaCl} 0.8 \%$ ) in $500 \mathrm{ml}$ flasks. In
TABLE 1: Characteristics of DK684RR2 maize seeds.

\begin{tabular}{l}
\hline General characteristics \\
Cicle: Intermediate \\
Behavior against common blight: Tolerant \\
Behavior against mal de Río Cuarto virus (MRCV): Tolerant \\
Relative Maturity: 119 \\
Type: Simple \\
\hline Characteristics of the ear \\
Cob diameter (cm): 2,3 \\
Shape of the ear: Cylindrical \\
Grains per row: 42 \\
Ear length (cm): $20-22$ \\
Number of rows: 14 \\
Grain/cob relation: $82 \% / 18 \%$ \\
\hline Characteristics of the plant \\
Height (cm): 219 \\
Leaf angle: $30^{\circ}$ \\
Husks: Medium/half-open \\
Number of leaves: 21 \\
Ear position at harvest: Do not overturn \\
\hline Characteristics of the grains \\
Color: Orange/Yellow \\
Hardness: Hard \\
Weight of 1000 (g): 328 \\
\hline
\end{tabular}

treatment two $(\mathrm{T} 2:+\mathrm{Ba}), 300$ seeds were submerged in $500 \mathrm{ml}$ flasks with $300 \mathrm{ml}$ of a suspension of $10^{9} \mathrm{CFU} \mathrm{ml} \mathrm{m}^{-1}$ of $B$. amyloliquefaciens. Finally, the third treatment (T3: + Mo) consisted of 300 seeds submerged in $500 \mathrm{ml}$ flasks with

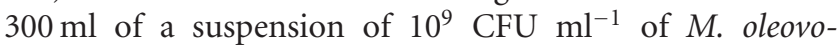
rans. Afterwards, inoculated suspensions were incubated for $30 \mathrm{~min}$ at $28^{\circ} \mathrm{C}$ with shaking $(100 \mathrm{rpm})$ to allow bacteria to adhere to seeds. Immediately before sowing, three replicates of $10 \mathrm{~g}$ of seeds from every different treatment were placed in flasks with $90 \mathrm{ml}$ of sterile phosphate buffered saline solution (PBS: $\mathrm{NaCl} 8 \mathrm{~g}, \mathrm{KCl} 0.2 \mathrm{~g}, \mathrm{Na}_{2} \mathrm{HPO}_{4} 1.15 \mathrm{~g}, \mathrm{KH}_{2} \mathrm{PO}_{4} 0.2 \mathrm{~g}$, distilled water $1000 \mathrm{~mL}, \mathrm{pH}$ 7.3) to estimate through serial dilutions and plate count the size of microbial inoculums that remained associated with the seeds. In all evaluated seasons, sowing took place during mid-November while harvest was performed during mid-March. These specific dates were chosen as they represent the growing season of maize in Argentina.

The field setup for all experiments followed a complete randomized block design with three replicates per treatment. Individual plots were $7 \mathrm{~m}$ long, $3 \mathrm{~m}$ wide and consisted in four rows planted to 25 seeds per row. Three hundred maize seeds were sown per treatment (100 per treatment-replica). Three rows sown with untreated maize seeds were used to separate adjacent plots and to surround the periphery of the entire planting. Soil presented a sandy loam texture $(\mathrm{pH} 6.1$ in water $1: 1 \mathrm{w} / \mathrm{v}, 1.4 \%$ organic matter).

The plots were exposed to naturally occurring inoculum of $F$. verticillioides. 
2.4. Sampling. When plants reached physiological maturity (R6 phenologic state according to Ritchie and Hanway [17] scale), all cobs were harvested per treatment and replica during each of the four field assays. Immediately after harvesting, grains were separated from cobs by using a static threshing machine (Forti MA, Buenos Aires, Argentina).

2.5. Influence of Treatments on Grain Yield. After separation of grains from cobs, moisture contents of grains were determined by using a hygrometer (Delver HD1000D). Total grain yields ( $\mathrm{Kg}$ grain $\mathrm{ha}^{-1}$ ) were calculated for each treatment-replica according to current regulations for maize commercialization in Argentina [18], after adjusting humidity to $14.5 \%$.

2.6. Analysis of Fusarium verticillioides Infection and Fumonisin $B_{1}$ Content of Maize Grains at Harvest. All seeds from the same plot (treatment-replica) were milled together and homogenized by using an electric miller (RAS Mill, Romer Labs, USA). Primary milled samples obtained from the different individual plots ranged between 4 and $7 \mathrm{Kg}$. Representative subsamples were taken from each primary sample and were used to determine F. verticillioides counts and fumonisin $\mathrm{B}_{1}$ contents.

Two sub-samples of $10 \mathrm{~g}$ were taken from each treatmentreplica and individually added to flasks with $90 \mathrm{~mL}$ of PBS to obtain a $1 / 10$ dilution. Serial decimal dilutions were performed in sterile PBS up to $10^{-3}$, and $0.1 \mathrm{~mL}$ from each dilution was spread plated in triplicate on Nash-Snyder agar [19] for selective isolation of Fusarium species. Plates were incubated 7 days at $28^{\circ} \mathrm{C}$, and after incubation total count and count per colony type were performed. Colonies were purified on carnation leaf agar (CLA) according to the single-spore method described by Nelson et al. [19]. Purified cultures were incubated at $25^{\circ} \mathrm{C}$ with a daily light length of $12 \mathrm{~h}$, and F. verticillioides was identified according to Nelson et al. [19] and Leslie and Summerell [20].

Fumonisin contents were also analyzed from $10 \mathrm{~g}$ subsamples of milled grains obtained in duplicate from each treatment-replica by using high performance liquid chromatography (HPLC) according to the official method AOAC number 995.15 based on Shephard et al. [21]. Acetonitrile/water $(1: 1, \mathrm{v} / \mathrm{v})$ was used as extraction solvent. Extracts were cleaned by using anion exchange Bond-Elut cartridges (SAX $500 \mathrm{mg}$, VARIAN). Fumonisins were derivatized with orthophthaldehyde (OPA). HPLC equipment consisted of a Hewlett Packard (Palo Alto, CA, USA) workstation (Hewlett Packard 1100 pump connected to a Hewlett Packard 1046 fluorescence detector). Chromatographic separations were performed on a stainless steel C18 column (LunaPhenomenex, Torrance, CA, USA). Isocratic mobile phase used was methanol: sodium dihydrogen phosphate buffer, $\mathrm{pH} 3.35,0.1 \mathrm{M}(77: 23, \mathrm{v} / \mathrm{v})$ with a flow rate of $1 \mathrm{~mL} / \mathrm{min}$.

2.7. Climatic Data. Air and soil daily maximum and minimum temperatures $\left({ }^{\circ} \mathrm{C}\right)$ and cumulative monthly rainfalls $(\mathrm{mm})$ were registered for the whole period of crop growth and development at field during the four consecutive analyzed seasons. Climatic data were obtained from the ADCON Telemetry Field Station [22] located immediately next to the experimental area.

2.8. Data Analysis. Fusarium verticillioides count from maize grains, $\mathrm{FB}_{1}$ contents at harvest as well as total yields were analyzed by using ANOVA for complete randomized block design (SAS for Windows 6.11, SAS Institute, Cary, NC). Tukey test was used for posteriori comparisons between treatments. When no significant block effects were observed, values from the different treatment replications were grouped together and averaged per treatment. Pearson product moment correlation coefficient (SigmaStat for Windows Version 3.5, Systat Software Inc., Germany) was used to analyze correlation between variables (yield, fumonisin $\mathrm{B}_{1}$ content, Fusarium verticillioides count, and rainfall values). Data were $\log _{10}$ transformed. A $P<0.05$ significance level was used throughout.

\section{Results and Discussion}

Studies based on control strategies using biological agents have increased over the last few years, mainly driven by the need for effective and environmentally friendly alternatives to the use of synthetic chemical pesticides.

The present work addressed the effects of two bacterial biocontrol agents on $F$. verticillioides infection of field-grown maize and fumonisin $B_{1}$ content of grains at harvest during four consecutive growing seasons. This survey also assessed the interactions between different variables that may alter maize phytosanitary quality.

3.1. Maize Yields. Bacteria from different genera have shown potential to improve crop yields; within these microorganisms, rhizosphere-associated nitrogen fixing and phosphatesolubilizing bacteria have been used as inoculums for nonlegume crop species such as maize, rice, wheat, and sugarcane $[23,24]$. However, we observed that yields obtained after treatment with $B$. amyloliquefaciens and M. oleovorans (T2 and T3, resp.) did not differ significantly from those of the control during all evaluated seasons (Table 3). Biocontrol agents of the present study did not show plant promoting effects in none of the assay field trials, thus indicating that they do not act as biofertilizers. Nevertheless, they neither presented plant growth retarding effects, which have been reported in various studies evaluating pathogen-antagonistic abilities of bacterial agents [25-27].

Rainfall regimes markedly affected total yields at harvest. In this sense, during the 2005-2006 assay, cumulative rainfall values were the lowest among the different field trials ( $449 \mathrm{~mm}$ from sowing to harvest, Table 2) and so were the obtained grain yields (3050 kg in the control), while during the 2006-2007 assay, when a rainfall cumulative value of $732 \mathrm{~mm}$ was registered, yields were maximum $(6429 \mathrm{~kg}$ in the control). Correlation between these two variables (yield and rainfall values) was positive $(0.61)$ but not significant (Table 4). Plants grown from seeds coated with either $B$. 
TABLE 2: Monthly rainfall and air temperatures registered in the different field assays.

\begin{tabular}{lcccccccc}
\hline \multirow{2}{*}{ Month } & \multicolumn{2}{c}{$2004-2005$} & \multicolumn{2}{c}{$2005-2006$} & \multicolumn{2}{c}{$2006-2007$} & \multicolumn{2}{c}{$2007-2008$} \\
& Rainfall & Temperature & Rainfall & Temperature & Rainfall & Temperature & Rainfall & Temperature \\
\hline November & 50 & $20.0(13-27)^{+}$ & 92 & $22.0(14-30)$ & 165 & $20.5(13-28)$ & 50 & $20.5(12-29)$ \\
December & 130 & $22.0(15-29)$ & 42 & $23.0(15-31)$ & 160 & $23.0(16-30)$ & 140 & $22.0(14-30)$ \\
January* & 270 & $23.0(16-30)$ & 116 & $24.0(16-32)$ & 168 & $22.5(16-29)$ & 213 & $23.0(16-30)$ \\
February & 165 & $22.0(16-28)$ & 105 & $22.0(15-29)$ & 155 & $22.0(15-29)$ & 94 & $22.3(15-29.5)$ \\
March & 80 & $19.5(12-27)$ & 94 & $20.0(12.5-27.5)$ & 84 & $20.3(14-26.5)$ & 145 & $20.5(13-28)$ \\
\hline Total & 695 & - & 449 & - & 732 & - & 642 & -
\end{tabular}

Values correspond to cumulative monthly rainfalls $(\mathrm{mm})$ and medium air temperatures $\left({ }^{\circ} \mathrm{C}\right)$ registered at field during four consecutive maize growing seasons (2004-2005, 2005-2006, 2006-2007 and 2007-2008). Sowing was performed during mid November and harvest during late March. * Flowering date. ${ }^{+}$Monthly mean minimum and maximum temperatures.

TABLE 3: Yield, F. verticillioides count and fumonisin contents of maize grains harvested during four consecutive growing seasons.

\begin{tabular}{|c|c|c|c|c|}
\hline & 2004-2005 & $2005-2006$ & $2006-2007$ & $2007-2008$ \\
\hline & \multicolumn{4}{|c|}{ Yield $\left(\mathrm{Kg} \mathrm{ha}^{-1}\right)^{*}$} \\
\hline $\mathrm{T} 1(\mathrm{c})$ & $5900 \pm 200 \mathrm{a}$ & $3050 \pm 218 \mathrm{a}$ & $6429 \pm 398 a$ & $4081 \pm 497 \mathrm{a}$ \\
\hline $\mathrm{T} 2(+\mathrm{Ba})$ & $6050 \pm 577 \mathrm{a}$ & $3210 \pm 226 a$ & $7030 \pm 207 \mathrm{a}$ & $3452 \pm 399 a$ \\
\hline \multirow[t]{2}{*}{$\mathrm{T} 3(+\mathrm{Mo})$} & $5830 \pm 364 \mathrm{a}$ & $3175 \pm 363 \mathrm{a}$ & $6475 \pm 412 \mathrm{a}$ & $3434 \pm 404 \mathrm{a}$ \\
\hline & \multicolumn{4}{|c|}{ Fumonisin $\mathrm{B}_{1}$ content $(\mathrm{ppm})^{* *}$} \\
\hline $\mathrm{T} 1(\mathrm{c})$ & $2.65 \pm 0.24 \mathrm{a}$ & $4.27 \pm 0.41 \mathrm{a}$ & $0.04 \pm 0.01 \mathrm{a}$ & $1.24 \pm 0.05 \mathrm{a}$ \\
\hline $\mathrm{T} 2(+\mathrm{Ba})$ & $0.15 \pm 0.01 \mathrm{~b}$ & $2.48 \pm 0.16 b$ & $0.03 \pm 0.01 \mathrm{a}$ & $0.65 \pm 0.04 b$ \\
\hline \multirow[t]{2}{*}{$\mathrm{T} 3(+\mathrm{Mo})$} & $1.86 \pm 0.04 c$ & $3.45 \pm 0.21 \mathrm{c}$ & $0.04 \pm 0.01 \mathrm{a}$ & $0.23 \pm 0.06 c$ \\
\hline & \multicolumn{4}{|c|}{ Fusarium verticillioides count (CFU g g grain) ${ }^{* * *}$} \\
\hline $\mathrm{T} 1(\mathrm{c})$ & $1.05 \times 10^{3} \pm 2.12 \times 10^{2} \mathrm{a}$ & $1,66 \times 10^{5} \pm 1,07 \times 10^{2} \mathrm{a}$ & $3,11 \times 10^{4} \pm 4.58 \times 10^{2} \mathrm{a}$ & $3,41 \times 10^{4} \pm 7,23 \times 10^{1} a$ \\
\hline $\mathrm{T} 2(+\mathrm{Ba})$ & $1.50 \times 10^{2} \pm 7.07 \times 10^{1} \mathrm{~b}$ & $1,78 \times 10^{3} \pm 1,17 \times 10^{1} \mathrm{~b}$ & $1,26 \times 10^{3} \pm 1,38 \times 10^{1} \mathrm{~b}$ & $1.28 \times 10^{3} \pm 1.30 \times 10^{1} \mathrm{~b}$ \\
\hline T3 (+ Mo) & $3.50 \times 10^{2} \pm 7.00 \times 10^{1} \mathrm{~b}$ & $5,25 \times 10^{3} \pm 1,26 \times 10^{1} \mathrm{ab}$ & $1,50 \times 10^{4} \pm 1,60 \times 10^{2} \mathrm{ab}$ & $3,57 \times 10^{3} \pm 1.09 \times 10^{1} \mathrm{ab}$ \\
\hline
\end{tabular}

Treatments were sown at field and arranged in a complete randomized block design with 3 replications per treatment. Individual plots consisted in four rows with 25 seeds each. Adjacent plots were separated with three spacer rows sown with untreated seeds. Data are means and standard deviations of treatment replications since no significant block effects were observed. ${ }^{*}$ Data correspond to three determinations, ${ }^{* *}$ data correspond to three determinations performed in duplicate, and ${ }^{* * *}$ data correspond to six determinations performed in triplicate. Different letters indicate significant differences between treatments within the same season $(P<0.05$, ANOVA for complete randomized blocks). T1 (c): control seeds, T2 (+Ba): seeds treated with a suspension of $B$. amyloliquefaciens $10^{9} \mathrm{CFUs} \mathrm{ml}{ }^{-1}$, T3 (+Mo): seeds treated with a suspension of M. oleovorans $10^{9} \mathrm{CFUs} \mathrm{ml}^{-1}$.

amyloliquefaciens or M. oleovorans as well as control plants grew well, without showing symptoms of disease during the whole period of implantation at field in all evaluated assays.

It has been reported that the effect of maize inoculation with $F$. verticillioides on grain yields depends on the maize hybrid used [28]. Results of the present study cannot be contrasted with those reports since our assays were conducted under conditions of natural fungal infection and comprised the analysis of only one maize variety.

3.2. Fusarium verticillioides Infection of Maize Grains. F. verticillioides count performed from harvested grains varied according to the different growing seasons evaluated (Table 3), as it was observed for yields. While the average count of the fungus was between $10^{2}$ and $10^{3} \mathrm{CFU} \mathrm{g}^{-1}$ grain during the first evaluated season (2004-2005), count values reached the range of $10^{5}$ during the 2005-2006 season.

Inoculation with the biocontrol agent $B$. amyloliquefaciens (T2) significantly reduced $F$. verticillioides propagules in maize grains during all evaluated seasons while $M$. oleovorans treatment (T3) was effective in reducing this parameter only in one of the four assays (2004-2005). Data showed that despite not having PGPR effects on the maize crop, B. amyloliquefaciens consistently reduced fungal infection of maize ears through the different field assays. We also evidenced this antagonistic potential of B. amyloliquefaciens against $F$. verticillioides colonization of maize when performing greenhouse trials [16]. Antibiosis and competitive exclusion of the pathogen were proposed as key features of $B$. amyloliquefaciens that allow the control of F. verticillioides inoculum sizes among different maize tissues. The consistent effectiveness observed for this biological agent in the different field assays carried out represents a promising option for the control of $F$. verticillioides-maize interactions since classical control strategies are thought to lose effect against facultative endophytic pathogens like F. verticillioides. Previously reported results related to the infection of maize by this fungus range from systemic asymptomatic processes to severe rotting and wilting [ 9 , $28,29]$. Different factors may influence such a particular relation between $F$. verticillioides and maize within which fungal inoculum sizes, nutritional state of the plant, plant 
TABLE 4: Correlations between maize yield, fumonisin $B_{1}$ content and F. verticillioides count of harvested grains and rainfall values.

\begin{tabular}{lccc}
\hline & $\begin{array}{c}\text { Cumulative Rainfall } \\
\text { from flowering to } \\
\text { harvest }(\mathrm{mm})\end{array}$ & $\begin{array}{c}\text { Fumonisin } \mathrm{B}_{1} \text { content } \\
(\mathrm{ppb})\end{array}$ & $\begin{array}{c}\text { Fusarium verticillioides } \\
\text { count }\left(\mathrm{CFU} \mathrm{g}^{-1} \mathrm{grain}\right)\end{array}$ \\
\hline Yield $\left(\mathrm{kg} \mathrm{ha}^{-1}\right)$ & $r=0.613$ & $r=-0.688$ & $r=-0.802$ \\
Fusarium verticillioides count $\left(\mathrm{CFU} \mathrm{g}{ }^{-1}\right.$ grain) & $P=0.387$ & $P=0.312$ & $P=0.198$ \\
Fumonisin $\mathrm{B}_{1}$ content $(\mathrm{ppb})$ & $r=-0.926$ & $P=0.694$ & - \\
\hline
\end{tabular}

and fungal genotypes, and environmental conditions are more frequently reported [30-32].

Contrary to results obtained when evaluating correlation of yields with rainfall regimes (positive tendency to correlate), F. verticillioides count correlated negatively and significantly with rainfall values $(r=-0.926 ; P=0.045)$ (Table 4), thus indicating that scarce rain conditions are favorable to infection of maize grains with this pathogen. In agreement with this correlation tendency, Miller et al. [33] found that fungal infection and fumonisin production in maize was limited to drought-stressed fields. In the same sense, Bush et al. [34] found that maize grains with higher moisture content supported lower levels of $F$. verticillioides inoculums, while maximum infection took place in dry grains (dent stage, physiological maturity). However, factors other than water availability, such as the state of plant defenses and sugar content of the grains, may have played an important role in this result observed by Bush et al. [34].

Size of BCA inoculums that remained associated with the seeds at sowing (treatments 3 and 4) was between $2 \times 10^{6}$ and $4 \times 10^{6} \mathrm{CFU} \mathrm{g}^{-1}$ (data not shown). Other authors [35] have also reported that recovery of BCA inoculums from coated seeds was three orders of magnitude lower than count presented by original suspensions.

3.3. Fumonisin $B_{1}$ Content. Fumonisin occurrence constitutes a latent and imminent risk whenever $F$. verticillioides is present in the maize agroecosystem. Fumonisins are a group of molecules characterized by two tricarballylic acid side chains esterified to an aminopenthol backbone with one or more hydroxyl groups [36]. More than 20 classes of fumonisins have been described within which $\mathrm{FB}_{1}$ is the most abundantly produced and the most frequently found in maize and maize-based products $[37,38]$. This mycotoxin has gathered the interest of different regulatory organizations all over the world, mainly due to the health risks associated with the consumption of fumonisincontaminated food [39]. Ross et al. [40] and Thiel et al. [41] reported field outbreaks of leukoencephalomalacia in horses, associated with maize naturally contaminated with fumonisins. Motelin et al. [42] reported that pulmonary edema syndrome was associated with maize contaminated with $155 \mathrm{ppm}$ of fumonisin $\mathrm{B}_{1}$ fed to pigs, and Rheeder et al. [43] associated exposure to Fusarium verticillioides-infected maize contaminated with $\mathrm{FB}_{1}$ with oesophageal cancer in the Transkei, South Africa.
A maximum of $4.27 \mathrm{ppm}$ of $\mathrm{FB}_{1}$ was registered in control grains (T1) of the second evaluated season (Table 3 ). This result seems to present association with maximum levels of F. verticillioides infection found in harvested grains during this same season. Fumonisin $\mathrm{B}_{1}$ contents showed a tendency to correlate positively with $F$. verticillioides inoculum sizes $(r=0.694$, Table 4). Chulze et al. [44] also found a positive correlation between these two variables when studying the relationship between the fungal inoculum size and fumonisin production on irradiated maize grains.

As it was found for F. verticillioides count, fumonisin levels presented a tendency to correlate negatively with cumulative rainfall values (Table 4). In agreement with these results, Warfield and Gilchrist [45] found that growth of F. verticillioides and $\mathrm{FB}_{1}$ synthesis were strongly affected by moisture content of the substrate; they showed that the lower the moisture content, the higher the infection and toxin production of the fungus in maize. In addition to moisture content and rainfall regimes, the different agroecological zones where the crop is grown seem to affect total fumonisin contents of mature maize grains. In this regard, Thiel et al. [46] reported levels of $\mathrm{FB}_{1}+\mathrm{FB}_{2}$ between 3.77 and $140.48 \mathrm{ppm}$ in samples from Transkei, while Sydenham et al. [47] found levels between 1.59 and $9.90 \mathrm{ppm}$ in samples from Argentina; Doko et al. [48] informed maximum levels of $0.34 \mathrm{ppm}$ in samples from France, and Bittencourt et al. [49] found up to $19 \mathrm{ppm}$ in samples from Brazil.

Inoculation with either B. amyloliquefaciens (T2) or M. oleovorans (T3) promoted a significant reduction on $\mathrm{FB}_{1}$ contents of harvested grains during three of the four evaluated seasons (2004-2005, 2005-2006, and 2007-2008) while during the 2006-2007 season fumonisin levels were minimum (between $0.03 \mathrm{ppm}$ and $0.04 \mathrm{ppm}$ ) in all evaluated treatments. The lowest levels of $\mathrm{FB}_{1}$ were registered after treatment with B. amyloliquefaciens (T2).

There are no international regulations for fumonisin accepted levels in maize intended for human consumption. A recommendation of the Official Journal of the European Union [50] set values between 5 and $60 \mathrm{ppm}$ of $\mathrm{FB}_{1}+\mathrm{FB}_{2}+\mathrm{FB}_{3}$ as recommended levels for these toxins in maize intended for poultry and livestock food. The Center for Food and Drug Administration recommended total values of $\mathrm{FB}_{1}+\mathrm{FB}_{2}$ up to $3 \mathrm{ppm}$ for maize intended for human consumption [51]. According to these facts, $\mathrm{FB}_{1}$ levels registered in the different field trials of the present study fall within recommended levels, with only one exception 
( $\mathrm{FB}_{1}$ content of control grains during 2005-2006 season). In spite of the obtaining of low fumonisin contents at field, results suggest that inoculation with either $B$. amyloliquefaciens or M. oleovorans may improve maize phytosanitary quality, allowing the harvest of grains with low fumonisin amounts in years conducive for F. verticillioides infection or under conditions that stimulate toxin synthesis. Additionally, proper harvest and storage procedures need to be followed to ensure a safe product with minimum mycotoxin levels.

\section{Acknowledgment}

This work was carried out through grants from Agencia Nacional de Promoción Científica y Tecnológica (ANPCyT, FONCYT-PICT START UP 1521/06). SECyT-UNRC 20092010. Res. 807/09.

\section{References}

[1] J. von Braun, The World Food Situation. New Driving Forces and Required Actions, International Food Policy Research Institute (IFPRI), Washington, DC, USA, 2007.

[2] FAO, Food and Agriculture Organization of the United Nations, "FAOSTAT, crop production statistics, maize," 2011, http://faostat.fao.org/site/291/default.aspx .

[3] SAGPyA, Secretaría de Agricultura, Ganadería, Pesca y Alimentos, "Reports on cereals, maize. Reports per crop, Dirección de Coordinación de Información, delegaciones y elaboración de estimaciones agropecuarias," 2008, http://www .sagpya.gov.ar.

[4] D. Pimentel and T. W. Patzek, "Ethanol production using corn, switchgrass, and wood; biodiesel production using soybean and sunflower," Natural Resources Research, vol. 14, no. 1, pp. 65-76, 2005.

[5] ILSI, Internacional Life Sciences Institute, "Maíz y nutrición. Informe sobre los usos y las propiedades nutricionales del maíz para la alimentación humana y animal," in Recopilación de ILSI Argentina, vol. 2 of Serie de Informes Especiales, 2006.

[6] R. K. Osboo, M. Mirabolfathy, and F. Aliakbari, "Natural deoxynivalenol contamination of corn produced in Golestan and Moqan areas in Iran," Journal of Agricultural Science and Technology, vol. 12, no. 2, pp. 233-239, 2010.

[7] S. L. Lenardón, "Enfermedades endémicas y emergentes de las plantas cultivadas," Revista Ciencia Hoy, vol. 13, no. 74, 2003.

[8] C. W. Bacon and I. E. Yates, "Endophytic root colonization by Fusarium species: histology, plant interactions and toxicity," in Microbial Root Endophytes, B. J. E. Schulz, C. J. C. Boyle, and T. N. Sieber, Eds., Springer, Heidelberg, Germany, 2006.

[9] C. W. Bacon, A. E. Glenn, and I. E. Yates, "Fusarium verticillioides: managing the endophytic association with maize for reduced fumonisins accumulation," Toxin Reviews, vol. 27, no. 3-4, pp. 411-446, 2008.

[10] IARC, International Agency for Research on Cancer, "Fumonisin $\mathrm{B}_{1}$. Some traditional herbal medicines, some mycotoxins, naphthalene and styrene," IARC Monographs on the Evaluation of Carcinogenic Risks to Humans, vol. 82, pp. 301-366, 2002.

[11] R. N. Strange and P. R. Scott, "Plant disease: a threat to global food security," Annual Review of Phytopathology, vol. 43, pp. 83-116, 2005.

[12] P. Koirala, S. Dhakal, and A. S. Tamrakar, "Pesticide application and food safety issue in Nepal," The Journal of Agriculture and Environment, vol. 10, pp. 111-114, 2009.
[13] C. Potera, "Pesticides disrupt nitrogen fixation," Environmental Health Perspectives, vol. 115, no. 12, p. 579, 2007.

[14] R. A. Slepecky and H. E. Hemphill, "The genus Bacillus," in The Prokaryotes. A Handbook on the Biology of Bacteria: Ecophysiology, Isolation, Identification, Applications, A. Balows, H. G. Trüper, M. Dworkin, W. Harder, and K. Schleifer, Eds., p. 4126, Springer, New York, NY, USA, 1992.

[15] J. G. Holt, N. R. Krieg, P. H. A. Sneath, J. T. Staley, and S. T. Williams, Bergey's Manual of Determinative Bacteriology, Williams \& Wilkins, Baltimore, Md, USA, 9th edition, 1994.

[16] P. Pereira, A. Nesci, and M. Etcheverry, "Efficacy of bacterial seed treatments for the control of Fusarium verticillioides in maize," BioControl, vol. 54, no. 1, pp. 103-111, 2009.

[17] S. W. Ritchie and J. J. Hanway, "How a corn plant develops," Special Report 48, University of Science and Technology. Cooperative Extension Service, Ames, Iowa, USA, 1982.

[18] SAGPyA, Secretaría de Agricultura, Ganadería, Pesca y Alimentos, "Norma de comercialización de maíz 1075/94. norma XII," 1994, http://www.cosechaypostcosecha.org/data/postcosecha/basescomercializacion/basescomercializacionmaiz.pdf.

[19] P. E. Nelson, T. A. Toussoun, and W. F. O. Marasas, Fusarium Species: An Illustrated Manual for Identification, Pennsylvania State University, University Park, Pa, USA, 1983.

[20] J. F. Leslie and B. A. Summerell, The Fusarium Laboratory Manual, Blackwell Publishing Professional, Ames, Iowa, USA, 2006.

[21] G. S. Shephard, E. W. Sydenham, P. G. Thiel, and W. C. A. Gelderblom, "Quantitative determination of fumonisins $B_{1}$ and $\mathrm{B}_{2}$ by HPLC with fluorescence detection," Journal of Liquid Chromatography, vol. 13, no. 10, pp. 2077-2087, 1990.

[22] ADCON Telemetry Field Station, Dependent of Aseagro and Universidad Nacional de Río Cuarto http://www.aseagro.com.ar.

[23] J. Dobereiner, "Biological nitrogen fixation in the tropics: social and economic contributions," Soil Biology and Biochemistry, vol. 29, no. 5-6, pp. 771-774, 1997.

[24] G. Schilling, A. Gransee, A. Deubel, G. Lezovic, and S. Ruppel, "Phosphorus availability, root exudates and microbial activity in the rhizosphere," Zeitschrift für Pflanzenernährung und Bodenkunde, vol. 161, pp. 465-478, 1998.

[25] J. Sørensen, "The rhizosphere as a habitat for soil microorganisms," in Modern Soil Microbiology, J. D. van Elsas, J. T. Trevors, and E. M. H. Wellington, Eds., pp. 21-45, Marcel Dekker, New York, NY, USA, 1997.

[26] J. Kozdrój, J. T. Trevors, and J. D. van Elsas, "Influence of introduced potential biocontrol agents on maize seedling growth and bacterial community structure in the rhizosphere," Soil Biology and Biochemistry, vol. 36, no. 11, pp. 1775-1784, 2004.

[27] F. Ciccillo, A. Fiore, A. Bevivino, C. Dalmastri, S. Tabacchioni, and L. Chiarini, "Effects of two different application methods of Burkholderia ambifaria MCI 7 on plant growth and rhizospheric bacterial diversity," Environmental Microbiology, vol. 4, no. 4, pp. 238-245, 2002.

[28] D. A. Presello, G. Botta, J. Iglesias, and G. H. Eyhérabide, "Effect of disease severity on yield and grain fumonisin concentration of maize hybrids inoculated with Fusarium verticillioides," Crop Protection, vol. 27, no. 3-5, pp. 572-576, 2008.

[29] A. E. Desjardins, R. D. Plattner, M. Lu, and L. E. Claflin, "Distribution of fumonisins in maize ears infected with strains of Fusarium moniliforme that differ in fumonisin production," Plant Disease, vol. 82, no. 8, pp. 953-958, 1998.

[30] M. J. Cantalejo, J. M. Carrasco, and E. Hernández, "Incidence and distribution of Fusarium species associated with feeds and 
seeds from Spain," Revista Iberoamericana de Micologia, vol. 15, no. 1, pp. 36-39, 1998.

[31] J. D. Miller, "Factors affecting the occurrence of fumonisin in corn," in Proceedings of the International Conference on the Toxicology of Fumonisin, Arlington, Va, USA, June, 1999.

[32] P. Fandohan, K. Hell, W. F. O. Marasas, and M. J. Wingfield, "Infection of maize by Fusarium species and contamination with fumonisin in Africa," African Journal of Biotechnology, vol. 2, no. 12, pp. 570-579, 2003.

[33] J. D. Miller, M. E. Savard, A. W. Schaafsma, K. A. Seifert, and L. M. Reid, "Mycotoxin production by Fusarium moniliforme and Fusarium proliferatum from Ontario and occurrence of fumonisin in the 1993 corn crop," Canadian Journal of Plant Pathology, vol. 17, pp. 233-239, 1995.

[34] B. J. Bush, M. L. Carson, M. A. Cubeta, W. M. Hagler, and G. A. Payne, "Infection and fumonisin production by Fusarium verticillioides in developing maize kernels," Phytopathology, vol. 94, no. 1, pp. 88-93, 2004.

[35] F. G. Rojo, M. M. Reynoso, M. Ferez, S. N. Chulze, and A. M. Torres, "Biological control by Trichoderma species of Fusarium solani causing peanut brown root rot under field conditions," Crop Protection, vol. 26, no. 4, pp. 549-555, 2007.

[36] W. C. A. Gelderblom, K. Jaskiewicz, W. F. O. Marasas et al., "Fumonisins-novel mycotoxins with cancer-promoting activity produced by Fusarium moniliforme," Applied and Environmental Microbiology, vol. 54, no. 7, pp. 1806-1811, 1988.

[37] J. W. Bennett and M. Klich, "Mycotoxins," Clinical Microbiology Reviews, vol. 16, no. 3, pp. 497-516, 2003.

[38] B. H. Bluhm and C. P. Woloshuk, "Amylopectin induces fumonisin $B_{1}$ production by Fusarium verticillioides during colonization of maize kernels," Molecular Plant-Microbe Interactions, vol. 18, no. 12, pp. 1333-1339, 2005.

[39] P. Fandohan, B. Gnonlonfin, K. Hell, W. F. O. Marasas, and M. J. Wingfield, "Natural occurrence of Fusarium and subsequent fumonisin contamination in preharvest and stored maize in Benin, West Africa," International Journal of Food Microbiology, vol. 99, no. 2, pp. 173-183, 2005.

[40] P. F. Ross, A. E. Ledet, D. L. Owens et al., "Experimental equine leukoencephalomalacia, toxic hepatosis, and encephalopathy caused by corn naturally contaminated with fumonisins," Journal of Veterinary Diagnostic Investigation, vol. 5, no. 1, pp. 69-74, 1993.

[41] P. G. Thiel, G. S. Shephard, E. W. Sydenham, W. F. O. Marasas, P. E. Nelson, and T. M. Wilson, "Levels of fumonisins $B_{1}$ and $B_{2}$ in feeds associated with confirmed cases of equine leukoencephalomalacia," Journal of Agricultural and Food Chemistry, vol. 39, no. 1, pp. 109-111, 1991.

[42] G. K. Motelin, W. M. Haschek, D. K. Ness et al., “Temporal and dose-response features in swine fed corn screenings contaminated with fumonisin mycotoxins," Mycopathologia, vol. 126, no. 1, pp. 27-40, 1994.

[43] J. P. Rheeder, W. F. O. Marasas, P. G. Thiel, E. W. Sydenham, G. S. Shephard, and D. J. Van Schalkwyk, "Fusarium moniliforme and fumonisins in relation to human oesophageal cancer in Transkei," Phytopathology, vol. 82, pp. 353-357, 1992.

[44] S. N. Chulze, M. Etcheverry, S. Lecumberry et al., "Fumonisin production on irradiated corn kernels: effect of inoculum size," Journal of Food Protection, vol. 62, no. 7, pp. 814-817, 1999.

[45] C. Y. Warfield and D. G. Gilchrist, "Influence of kernel age on fumonisin $\mathrm{B}_{1}$ production in maize by Fusarium moniliforme," Applied and Environmental Microbiology, vol. 65, no. 7, pp. 2853-2856, 1999.
[46] P. G. Thiel, W. F. O. Marasas, E. W. Sydenham, G. S. Shephard, and W. C. A. Gelderblom, "The implications of naturally occurring levels of fumonisins in corn for human and animal health," Mycopathologia, vol. 117, no. 1-2, pp. 3-9, 1992.

[47] E. W. Sydenham, G. S. Shephard, P. G. Thiel, and W. F. O. Marasas, "Fumonisins in Argentinian field-trial corn," Journal of Agricultural and Food Chemistry, vol. 41, no. 6, pp. 891-895, 1993.

[48] M. B. Doko, S. Rapior, A. Visconti, and J. E. Schjøth, "Incidence and levels of fumonisin contamination in maize genotypes grown in Europe and Africa," Journal of Agricultural and Food Chemistry, vol. 43, no. 2, pp. 429-434, 1995.

[49] A. B. F. Bittencourt, C. A. F. Oliveira, P. Dilkin, and B. Corrêa, "Mycotoxin occurrence in corn meal and flour traded in São Paulo, Brazil," Food Control, vol. 16, no. 2, pp. 117-120, 2005.

[50] Official Journal of the European Union, "Commission recommendation of 17 August on the prevention and reduction of Fusarium toxins in cereals and cereal products," 2006, http://eurlex.europa.eu/LexUriServ/LexUriServ.do?uri= OJ:L:2006:234:0035:0040:EN:PDF.

[51] FDA, Food and Drug Administration, "Background paper in support of fumonisin levels in corn and corn products intended for human consumption," Center for Food Safety and Applied Nutrition, 2001, http://www.fda.gov/Food/FoodSafety/FoodContaminantsAdulteration/NaturalToxins/ucm 212899.htm. 


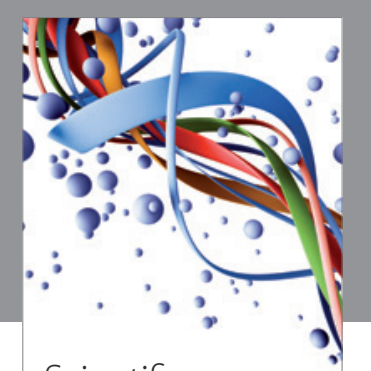

Scientifica
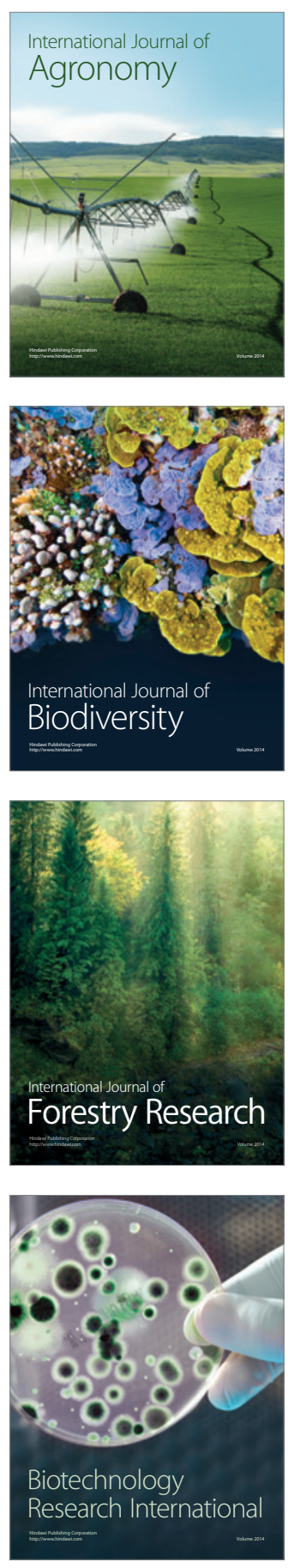
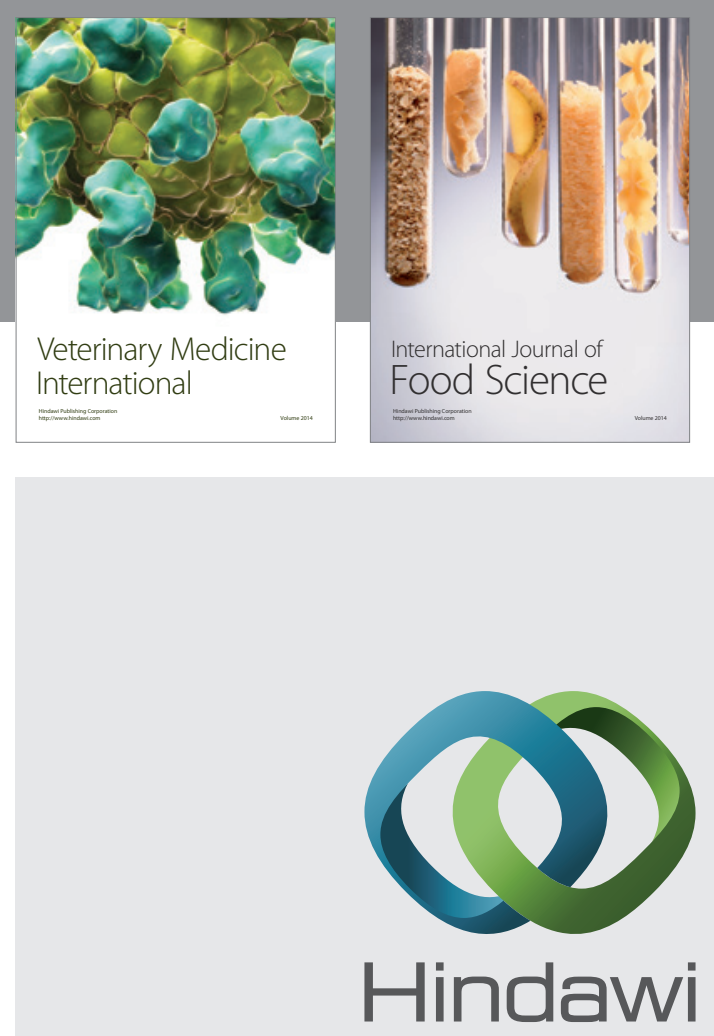

Submit your manuscripts at

http://www.hindawi.com
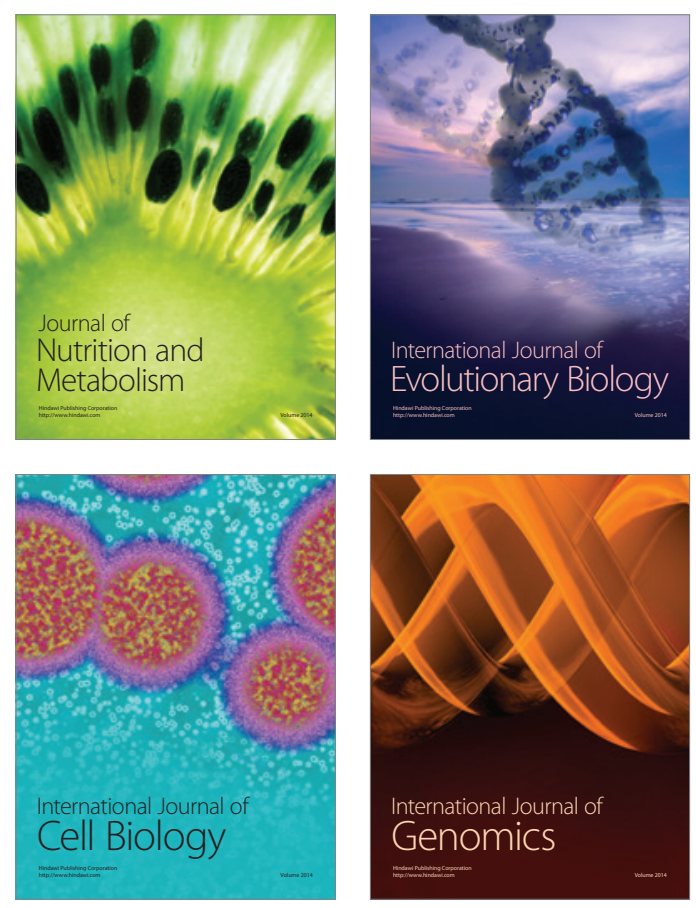
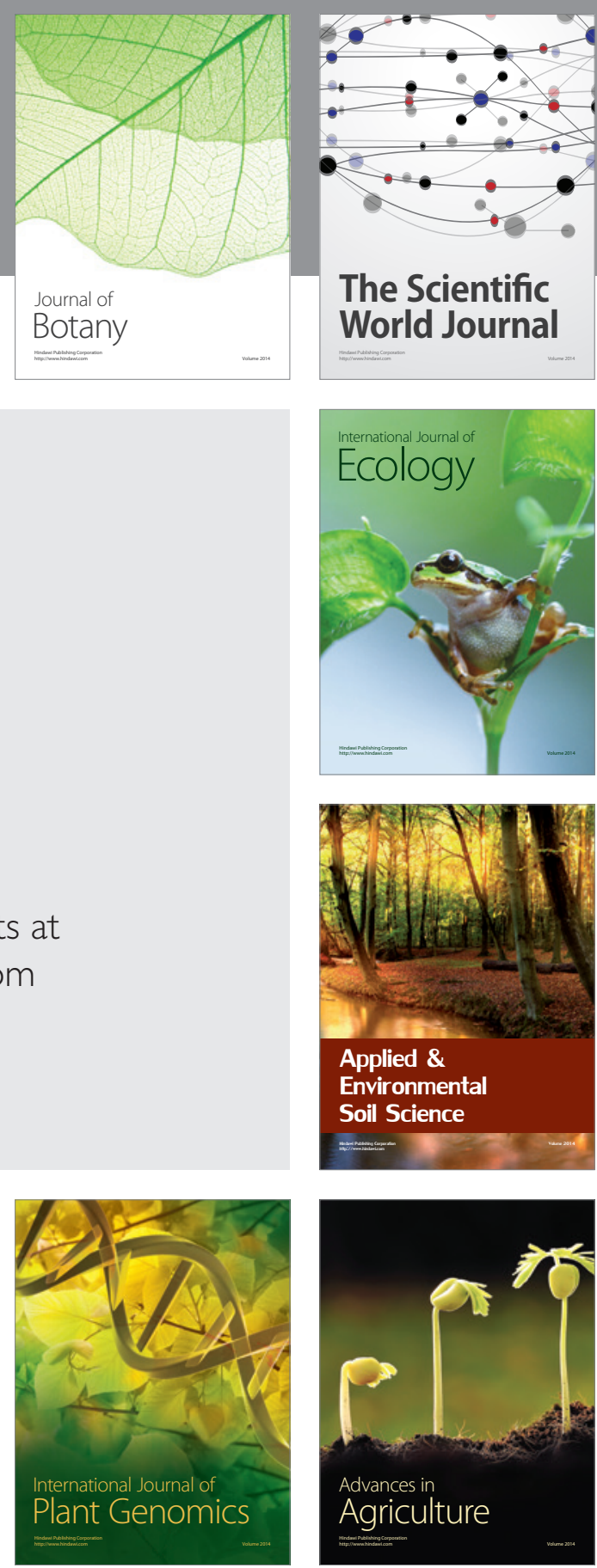

The Scientific World Journal
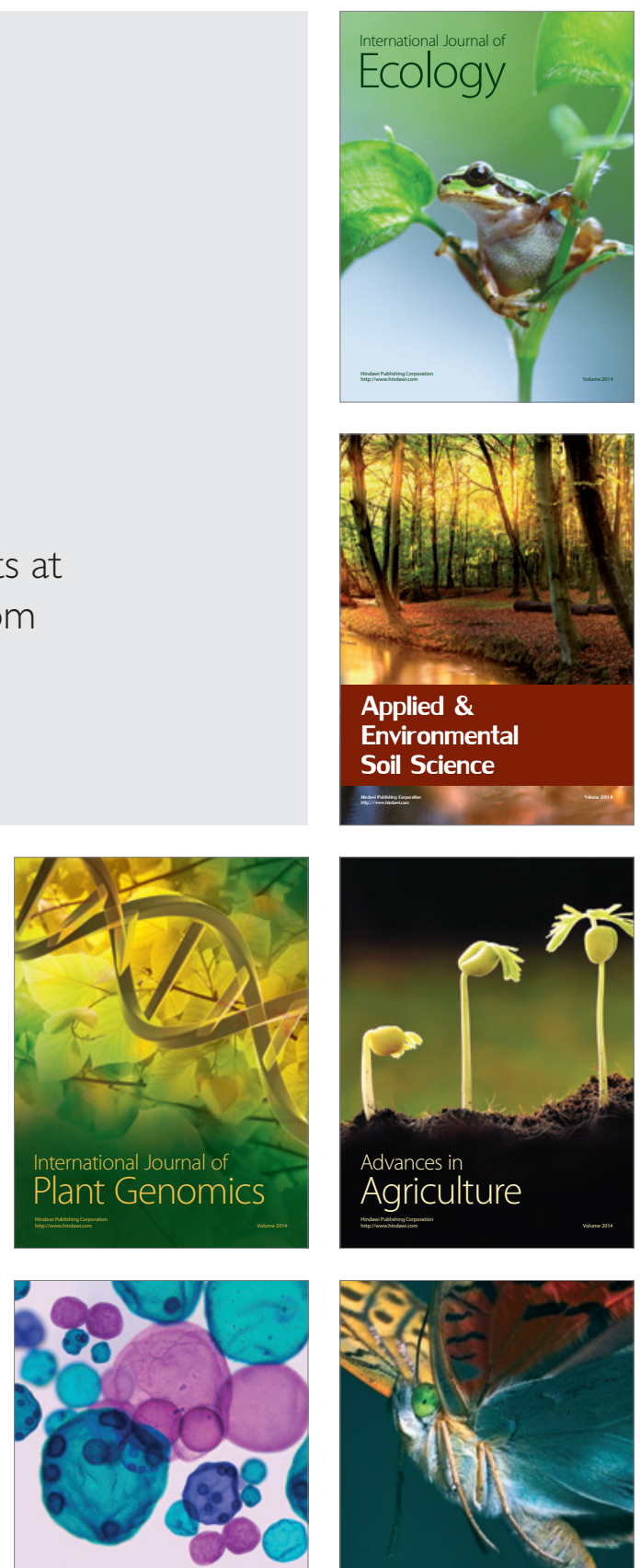

International Journal of Microbiology

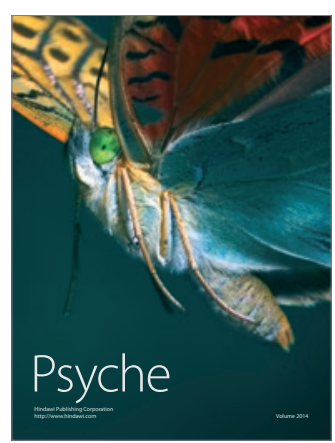

